\title{
Terraformation of Mars
}

\section{Teraformace Marsu}

\author{
Michael Gabriel \\ diplomová práce byla obhájena $\mathrm{v}$ roce 2018 \\ Fakulta architektury, Vysoké učení technické v Brně \\ vedoucí práce: Ing. arch. Jan Mléčka, Ph.D.
}

\begin{abstract}
ABSTRAKT: Osídlení Marsu je pro lidstvo existenčně důležitý úkol, a ve stejné míře důležitý i ve smyslu poznání, je prvím krokem člověka mimo náš planetární systém. Celá problematika osídlení Marsu se skládá $\mathrm{z}$ mnoha problémů již vyřešených, řešitelných a zatím neznámých. Jak v jednotlivých problémech, tak v celém plánu osídlení, existuje nepřeberné množství řešení, ale dají se shrnout do tří hlavních skupin úkolů: dostat lidi na Mars, udržet se na Marsu na živu, udělat z Marsu planetu obyvatelnou pro člověka.

Třetí ze tří hlavních skupin úkolů je nejzajímavější, časově nejnáročnější, ale, i když se to nezdá, principiálně nejjednodušší. $V$ principu tohoto úkolu jde o to, ohřát Mars, čímž se odstartuje řetězec procesů, které povedou k obnovení husté atmosféry, dále je třeba přidat život, pokud tam už není, a ten se během následujících 100000 let $( \pm 10 \%)$ postará o dýchatelnou atmosféru pro člověka.

S ohříváním planety má lidstvo čerstvé zkušenosti a zatím se zdá, že to umí velmi dobře. Zbývají otázky k vážné diskuzi: Jestli do tohoto procesu zasahovat. Když zasahovat, tak jak? Urychlit, tento proces? Jak ho provázat s lidskou prrítomností? V této práci předpokládám, že jsme se rozhodli pro kolonizaci Marsu a jeho teraformaci.

Cílem této práce bylo navrhnout autonomní systém, který bude založený na místních zdrojích a minimálně závislý na importu ze Země. Tento systém bude založen na existujících, nebo v blízké době vyvinutelných technologiích. V porovnání s konkurenčními postupy by měl být šetrný k prostředí, slučitelný se souběžnou kolonizací a méně závislý na zásobování ze Země.
\end{abstract}




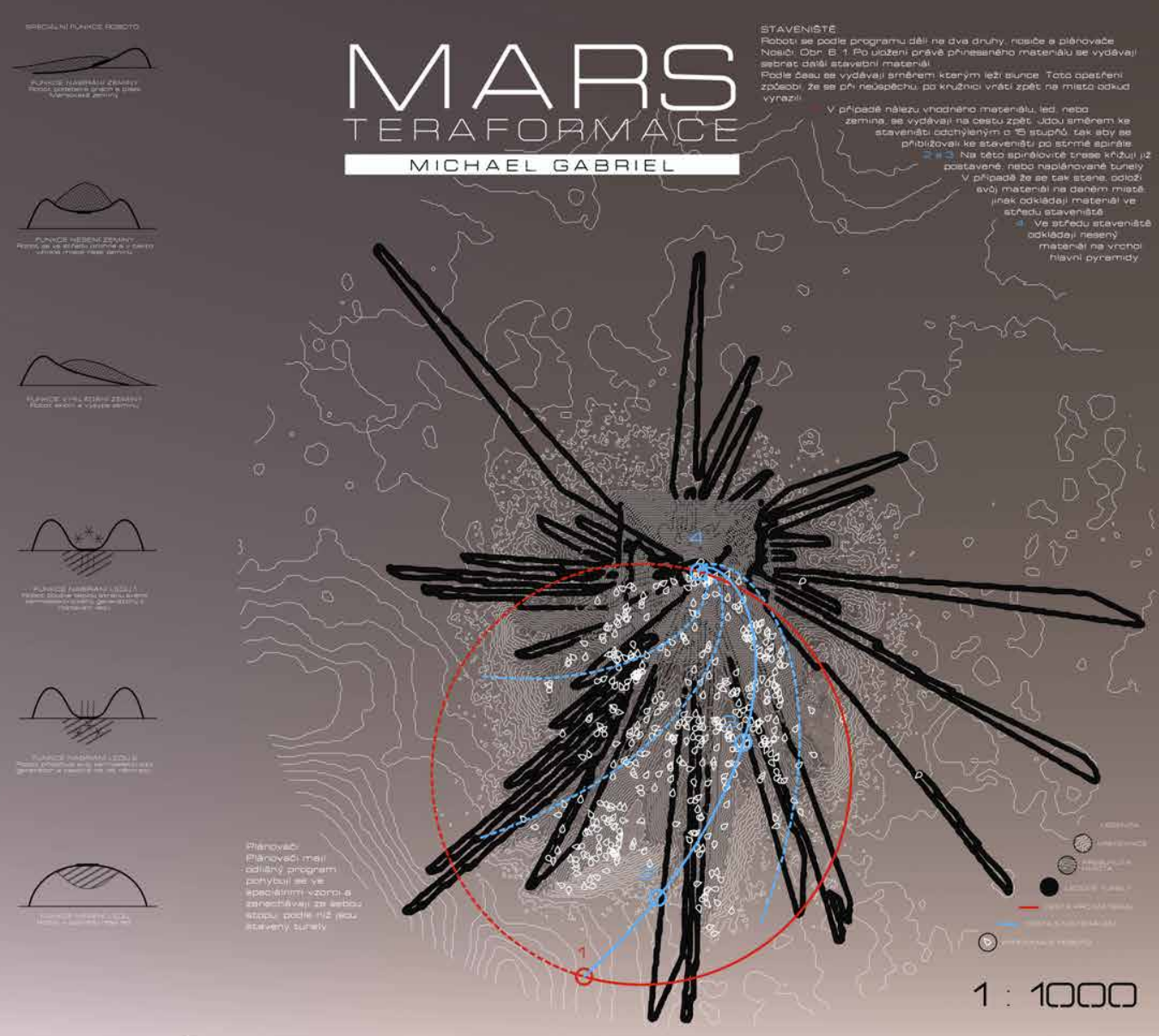
=

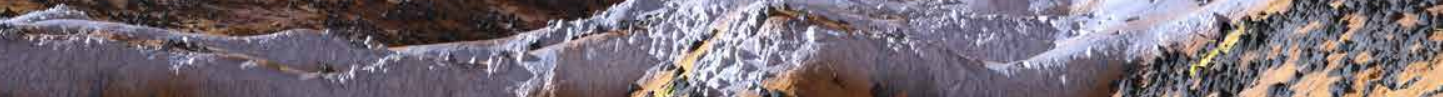

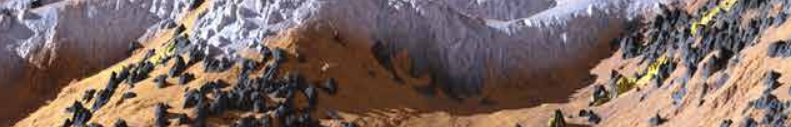
1.

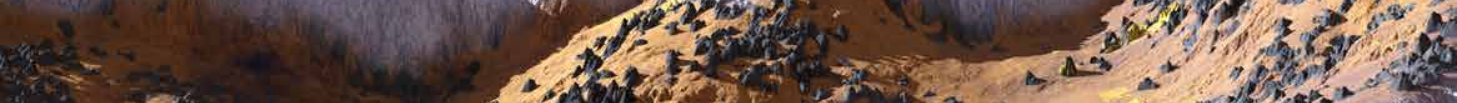

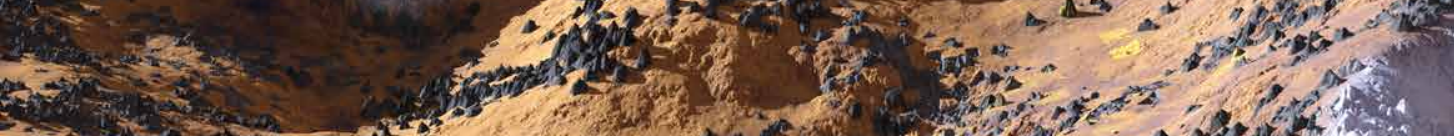
(2) (2)

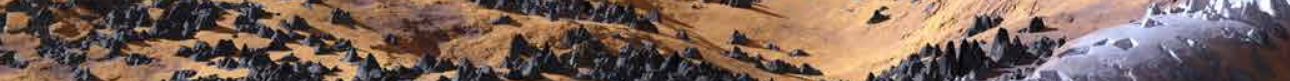

